\title{
GRANADAS: KATHERINE TO HER DAUGHTER
}

\author{
Christine Stewart-Nuñez
}

As a toddler, stumble-stepping in the palace, I sought quince jellythe fruit hard and sour until bletted or stewed. I adored azúcar rosado. almost as sweet the pomegranate, my badge. In Greece, it meant ambition; in Egypt, fruit of the dead. To the Spanish Jews my mother expelled, killed, or convertedproductivity. The first time I took one whole, I sliced open its leathery skin and ripped. Seeds burst, juice streaking white marble magenta. I plucked seventeen seeds and sucked one at a time, then chewed, bitter splinters on my tongue. The King, your father, planted the first pomegranate in England. The taste takes me home to the Alhambra's glistening pools, green gardens, hibiscus hedges of hot pink blossoms. In Hampton Court's Great Hall, look for my Coat of Arms and the branch carved to decorate the doorway. How prescient I was; granadas taken for weapons. Consider mine launched and rolled through time. See? The golden ovals are slit open to look like watching eyes. 